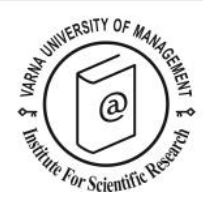

\title{
Residents' attitudes towards nightlife supply: A comparison of Ibiza (Spain) and Punta del Este (Uruguay)
}

\author{
José Ramón-Cardona ${ }^{1}$, Daniel Álvarez-Bassi² and \\ María Dolores Sánchez-Fernández ${ }^{3 *}$
}

\begin{abstract}
${ }^{1}$ Ibiza Island Council University College of Tourism, University of the Balearic Islands (Spain). C/ Bes, no 9. o780o Ibiza, Spain. e-mail: jose.ramon@uib.es

${ }^{2}$ Marketing and Tourism Research Center (Faculty of Business), Catholic University of Uruguay (Uruguay). Av. Roosevelt y Florencia, stop 7 \& 1/2, CP 20100 Punta del Este, Uruguay. e-mail: dalvarez@ucu.edu.uy

3 Department of Business (Faculty of Economics and Business), University of A Coruña (Spain). Campus de Elviña, s/n, 15071 Galicia, Spain. Telf: (+34) 881012565 e-mail: msanchezf@udc.es

* Corresponding author
\end{abstract}

\begin{abstract}
In coastal tourist destinations, there is nightlife, in addition to daytime leisure. For tourism development, it is of great relevance to take into account the resident population and their attitudes. In this paper, a comparison is made between Ibiza (Spain) and Punta del Este (Uruguay) in relation to the residents' attitudes towards nightlife. Specifically, the comparison is made by a descending cluster analysis, generating four groups of residents according to their attitudes (Enthusiasts, Moderates, Critics, and Negatives), and the distribution of these groups in the two regions is then compared. The most notable result is that the degree of acceptance of nightlife is low in both cases, possibly due to the problems attributed to it, but the score is slightly higher in the case of Punta del Este. In addition, the profile of those opposed to nightlife is different: In Ibiza, Critics predominate, with a generally contrary response, but recognizing positive elements, whilst in Punta del Este, Negatives predominate, with systematically negative responses to all items.
\end{abstract}

Keywords: Nightlife; Ibiza; Punta del Este; cluster analysis; residents' attitudes

Citation: Ramón-Cardona,J., Álvarez-Bassi, D. and Sánchez-Fernández, M.D. (2021). Residents' attitudes towards nightlife supply: A comparison of Ibiza (Spain) and Punta del Este (Uruguay). European Journal of Tourism Research 29, 2914 


\section{Introduction}

One of the peculiarities of the tourism sector is that there is direct contact between the residents of the producing area and the client - tourists-who by definition are not part of the resident population. This contact requires residents to be taken into account in the management of the sector, since the quality of the service would otherwise be seriously affected and the sector would not be sustainable in the long term (Besculides, Lee, \& McCormick, 2002; Gursoy, Jurowski, \& Uysal, 2002). This is materialized in the need to take into account the attitudes and opinions of residents in planning tourist destinations (Ap, \& Crompton, 1998; Maddox, 1985). In coastal tourist destinations it is very common to have a nightlife supply (Kamenidou, Mamalis, Kokkinis, \& Geranis, 2013; Serra, \& Ramón, 2017; Sönmez, Apostolopoulos, Theocharous, \& Massengale, 2013; Stylidis, Terzidou, \& Terzidis, 2008; Tutenges, 2012, 2013) that complements the sun and beach supply. In practice, tourists frequent the beaches during the day and nightlife establishments at night. However, nightlife generates important controversies among the resident population due to the potential problems attributed to it, which mainly refer to social and public health problems, including drug consumption (Allen et al., 2020; Labhartet al., 2020), violent behavior (Quigg, Bigland, Hughes, Duch, \& Juan, 2020), risky sexual relationships (Buttram, Kurtz, \& Paul, 2017), health problems (Dimitrijević, Mijić, \& ŠumaracPavlović, 2020), etc. In some tourist destinations, nightlife is a very important element of the supply and image, as is the case in Ibiza (Spain) and Punta del Este (Uruguay). The nightlife supply in urban tourist destinations such as Barcelona (Nofre, Giordano, Eldridge, Martins, \& Sequera, 2018), Belgrade (Todorovic, \& Bakir, 2005), Berlin (Garcia, 2018), Lisbon (Nofre, 2013; Nofre et al., 2019), London (Andersson, 2011; Garcia, 2018), Madrid (Aramayona, \& García, 2019), New York (Houser, 2018; Rees, 2019), and Sydney (Homan, 2019) is also important, but it has a different profile in those cases.

Research on nightlife is still not very abundant, and the existing literature focuses on describing the supply and analyzing the public health problems that it can generate. Papers on social or management issues are very scarce and analyses of the residents' attitudes even more so. Based on the case of casinos, it would be expected that the literature on the residents' attitudes would be abundant when it comes to a supply with significant negative impacts, but this is not the case for night life. The main objective of this article is to provide knowledge about residents' attitudes regarding the nightlife supply in holiday tourist destinations. Due to the usual heterogeneity of residents' attitudes, the analysis is focused on ascertaining the main groups of attitudes regarding the nightlife within the resident population. The analysis was carried out with data from two tourist destinations, in order to provide a greater validity through the use of two case studies. The analysis carried out is a cluster analysis on the residents' attitudes towards nightlife. In addition, a comparison of the two destinations was carried out, allowing the degree of generalization of the results obtained to be determined. Cluster analysis has been employed for several decades for residents' attitude analysis, but it has rarely been used to analyse specific types of tourism. The cluster analyses carried out in the last decades divide the analysed sample into three, four, or five groups, in the vast majority of cases. These groups have different views on tourism and the percentage that each group represents varies enormously (Ramón, \& Serra, 2015). The only cluster analysis applied to the nightlife sector is that by Serra and Ramón (2017), where they obtained three groups.

This article aims to present a cluster analysis and, secondarily, a comparison between two tourist destinations similar in size, but with different levels of nightlife development: Ibiza (Spain, Europe) and Punta del Este (Uruguay, South America). The comparison seeks to determine if there are differences in the size of the resident clusters defined. The structure of the paper is as follows: After the introduction, there is a section reviewing the literature and another for exposing the two case studies analysed; the following section presents the methodology (cluster analysis), the questionnaire, and how 
the data were collected; and finally, there is a section on the results and a section on the conclusions that highlights the main contributions.

\section{Literature Review}

The analysis of residents' attitudes has a long tradition in academic research on tourism and dates back to the end of the 1970s. Since then, many papers on residents' attitude analysis have appeared (Sharpley, 2014), normally applied to general or majority tourism in a specific tourist destination (e.g., Almeida, Peláez, Balbuena, \& Cortés, 2016; Besculides et al., 2002; Del Chiappa, \& Abbate, 2016; Gursoy, \& Rutherford, 2004; Gursoy et al., 2002; Jurowski, \& Gursoy, 2004; Özel, \& Kozak, 2017). Over the years, multiple analysis techniques and different theoretical paradigms have been used as the basis of published papers on residents' perceptions, attitudes, and opinions (Lankford, \& Howard, 1994). Despite this, it should be noted that the two theories most frequently mentioned in studies of residents' attitudes are the Social Exchange Theory and the Tourism Area Life Cycle (Nunkoo, \& Ramkissoon, 2009; Nunkoo, Smith, \& Ramkissoon, 2013). Both theories propose very intuitive ideas: The Social Exchange Theory (Ap, 1992) states that residents support tourism for the benefits they obtain from this activity, or for the improvement in the local quality of life (Biagi, Ladu, Meleddu, \& Royuela, 2020), whilst the Tourism Area Life Cycle (Butler, 1980) considers that tourist destinations go through phases similar to the Product Life Cycle and, in these phases, the residents' attitudes change. In empirical analyses, Social Exchange Theory predominates as a theoretical basis, and in sociological or historical studies, the Tourism Area Life Cycle predominates.

There is a group of studies analyzing the heterogeneity of residents' attitudes using cluster analysis (e.g., Del Chiappa, Atzeni, \& Ghasemi, 2018; Del Chiappa, Atzeni, Pung, \& Risitano, 2019; Gon, Osti, \& Pechlaner, 2016; Lundberg, 2015; Pavlić, Portolan, \& Puh, 2020; Ribeiro, Valle, \& Silva, 2013; Serra, \& Ramón, 2017; Sinclair-Maragh, Gursoy, \& Vieregge, 2015; Vareiro, Remoaldo, \& Ribeiro, 2013) and, although there are differences in the results of these studies, certain guidelines can be observed, which were summarized by Ramón and Serra (2015). The present article would be included in this group of previous works, but it would be an application focusing on a specific type of supply.

Most studies on residents' attitudes analyze tourism in a region as a whole. Analyses of specific types of tourism are much less abundant, although there are some exceptions: Enclave resorts (e.g., Hernandez, Cohen, \& Garcia, 1996); national parks (e.g., Hernandez et al., 1996); casinos and gambling (e.g., Choi, Song, Wang, \& Hwang, 2019; Lee, Kim, \& Kim, 2018; Li, Liu, \& Ali, 2018); and cruise tourism (e.g., Del Chiappa, \& Abbate, 2016; Del Chiappa et al., 2019), among others. It should be noted that the analysis of casinos and gambling is quite abundant and is the sector that could most easily be assimilated into nightlife, due to the concern generated by both sectors due to the negative social impacts. In analyses referring to casinos and gambling, measurement scales have been developed (e.g., Chen, \& Hsu, 2001; Sutton, \& Griffiths, 2008) and it has been determined that the Social Exchange Theory is valid (Kang, Lee, Yoon, \& Long, 2008), as is the case of a set of studies on residents' attitudes.

The cluster analyses of residents' attitudes that have been carried out thus far divide the analysed sample into various groups with different views on tourism: One group is more or less contrary; another group has ambiguous or neutral positions; and between one and three groups have favourable positions, but to different degrees and with nuances. In the cases in which this type of analysis was applied, the percentages that each group represented varied enormously, but the groups who found tourism favourable represented a higher percentage of the sample than those opposed to it (Ramón, \& Serra, 2015). 
In the case of nightlife, most of the bibliography considers nightclubs to be a mere context or setting for studies not directly related to business management or marketing. These are studies that analyse social or health problems that are considered serious and, in many cases, linked to or enhanced by nightlife and the social atmosphere of nightclubs. Examples of this are various studies on drug use, violent behaviour, sexual relationships, disasters in nightclubs, and social analysis in the context of nightlife.

Papers on drug consumption (e.g., Allen et al., 2020; Griffin, Callander, Duncan, \& Palamar, 2020; Labhart et al., 2020; Palamar, \& Keyes, 2020) take into account multiple types of recreational drugs, both legal and illegal. One area of study is the abuse of alcohol by club patrons. Among the drugs analysed in the studies are cocaine, heroin, and a wide range of synthetic drugs, with the prevention of the consequences of these drugs being the main objective of these studies. Some papers analyse tobacco use and focus on passive smokers.

Another negative impact analysed is violent behaviour (e.g., Quigget al., 2020; Sanchez, Santos, Sanudo, Carlini, \& Martins, 2019; Tomsen, 2018), including fights in or near clubs, sexual assaults in nightlife areas, and other types of violent crime. In many cases, these problems are considered to be potentiated by the use of recreational drugs. Drugs are also considered a risk factor for facilitating risky sex (Buttram, Pagano, \& Kurtz, 2018; Carlini, \& Sanchez, 2018; Palamar, Griffin-Tomas, Acosta, Ompad, \& Cleland, 2018). The main consequences of these risk relationships are possible sexually transmitted diseases, the risk of unwanted pregnancies, etc.

Nightclubs are establishments in which many people congregate in a small space. For this reason, with the current COVID-19 pandemic, they will be one of the last establishments to open to the public. However, they have always represented a major disaster hazard with many possible deaths from events such as fires, earthquakes, collapse of the structure, etc. In recent decades, there have been various cases of this type, and studies reviewing these disasters or suggesting improvements to the plans for club evacuation are not uncommon (e.g., Calegaro et al., 2019; Smith et al., 2020; Smith, Shapiro, \& Sarani, 2018).

Analyses from the social sciences focus on the interaction between individuals in the context of nightlife (e.g., Allmark \& Stratton, 2019; Baldor, 2019; Eldridge, 2019; Plyushteva, 2019; Søgaard, \& Krause-Jensen, 2019). In many cases, these studies analyze the problems indicated above, but from the perspectives of areas such as sociology, anthropology, criminology, or feminist theories. There is still a lack of statistical tools and observation, in-depth, or group interviews, and case studies as a methodology continue to predominate.

Studies that take nightlife, nightclubs, and their management as protagonists are scarcer; there are purely descriptive studies of nightlife and nightclubs (e.g., Allmark \& Stratton, 2019; Aramayona, \& García, 2019; Garcia, 2018; Homan, 2019; Houser, 2018; Nofre et al., 2019; Rees, 2019). These papers focus on describing the nightlife supply of specific cities or analyse urban areas that have undergone important changes due to the development of nightlife as a case study.

In the field related to management, there is a group of studies on servicescape (Kubacki, Skinner, Parfitt, \& Moss, 2007; Skinner, Kubacki, Parfitt, \& Moss, 2008; Skinner, Moss, \& Parfitt, 2005), some studies on the image of tourist destinations (Berrozpe, Campo, \& Yagüe, 2017; Stylidis et al., 2008) or establishments (Aagerup, 2020; Rivera, 2010), and studies on the residents' attitudes (Serra,\& Ramón, 2017).Serra and Ramón (2017) carried out the only cluster analysis relating to residents' attitudes 
towards the nightlife supply, and they obtained three groups (one favourable, one opposite, and one with intermediate positions), but there was not much enthusiasm among the supporters. Furthermore, the supporters were numerically similar to those opposed to the sector, probably due to concerns about the negative social impacts attributed to the sector.

\section{Case Studies}

Ibiza is an island of $572 \mathrm{~km} 2$ and part of the Balearic Islands (Spain), and has been highly dependent on tourism for decades. It currently has 147,00o inhabitants (Ibestat, 2020) and receives nearly 3,000,000 tourists a year, mostly concentrated in the months of May to October (AETIB, 2019). This implies that the island reaches a maximum of 350,000 people in August (Ibestat, 2020) and that human pressure causes exhaustion for residents. Since the emergence of the tourism sector, Ibiza has been a region associated with the image of freedom linked to artists of the European avant-garde that arrived in the 1930 and 1950s, to the beatniks of the 1950 s and 1960s, and to the hippies of the 1960s and 1970s. This concept of freedom favoured the appearance of the first nightlife offer on the island in the late $1950 \mathrm{~s}$ and it was revolutionary in its early days. The festive and ground-breaking customs of hippies had a high media impact at the time and, in some cases, gave rise to traditions observed in today's society. Finally, the first nightclubs appeared in the 1970s and some have continued to the present day (Ramón, 2001).

The international image of Ibiza, linked to beaches and nightlife (Berrozpe et al., 2017), is due to a small group of nightclubs characterized by the spectacular nature of their parties and the size of their halls (Ramón, \& Serra, 2014). Although Ibiza stands out internationally for its nightclubs and nightlife, scientific articles on the island's nightlife are as biased as in the rest of the world and are a context for analysing alcohol and drug use (e.g., Kelly, Hughes, \& Bellis, 2014; Martinotti et al., 2017; Turner, 2018), violent behavior (Calafat et al., 2013a, 2013b), and risky sexual behaviour (e.g., Downing et al., 2011; Kelly et al., 2014; O'Leary, Huan, Briggs, \& Turner, 2012). On the other hand, the local vision and analyses in areas such as geography and the economy are still quite absent, although there are some exceptions (e.g., Capellà, 2018; Ramón, Azpelicueta, Abril, \& Sánchez, 2020; Serra, \& Ramón, 2017).

Punta del Este is an international sun and beach tourist destination-the most important in the Eastern Republic of Uruguay and one of the most important in South America-mainly aimed at demand from Argentina. Punta del Este's city centre has just over 9200 residents, but it is part of a larger conurbation. The Maldonado-Punta del Este conurbation has more than 100,00o residents and is one of the most populated areas in the country. In 2019, Punta del Este received 584,00o tourists, who stayed at the destination for an average of 7.5 days. The arrival of tourists is concentrated in the high season months, from December to February (Ministerio de Turismo, 2020). It is considered one of the most exclusive and reputed destinations in the region, but it does not have a tourist supply clearly aimed at young tourism, as in the case of other sun and beach destinations with internationally renowned nightclubs, such as Ibiza, Pag, \& Mykonos.

The supply of nightlife in Punta del Este consists of nightclubs and pubs. There are about ten large nightclubs: Four are only open during the summer, but the rest are open all year round. This is supplemented with fifty pubs. A significant part of the nightlife can be found in the area of La Barra, located 10 kilometres from the centre of Punta del Este. La Barra has important nightclubs and pubs and therefore makes it possible to remove the nightlife from the city centre, reducing the negative impact on residents. 


\section{Methodology}

\section{Research Background}

In studies on residents' attitudes, the residents' attitude variability has been analysed from the start, and articles that segment residents according to their perceptions and attitudes towards the tourism sector are still common (e.g., Del Chiappa et al., 2018; Del Chiappa et al., 2019; Gon et al., 2016; Lundberg, 2015; Pavlić et al., 2020; Ribeiro et al., 2013; Serra, \& Ramón, 2017; Sinclair-Maragh et al., 2015; Vareiro et al., 2013).

If there are differences between people residing in the same region, even more can occur between regions. This has led to a small group of studies comparing the residents' attitudes in two or more regions. In some cases, they are regions with clear socio-demographic differences (e.g., Lundberg, 2015; Rasoolimanesh, Ringle, Jaafar, \& Ramayah, 2017), and in other cases, they are regions with important similarities (e.g., Figueiredo, Kastenholz, \& Pinho, 2014; Garau, Díaz, \& Gutierrez, 2014; Nejati, Mohamed, \& Omar, 2014; Xiaoping, Zhu, \& Deng, 2014). In this paper, two destinations are compared by performing a segmentation of residents based on their attitudes towards a specific type of supplynightlife.

In order to make the comparison between the two destinations, a cluster analysis on the eight items referring to aspects of night life was carried out. Cluster analysis is a statistical tool that allows a sample to be segmented into groups or subsamples that are characterized by greater internal homogeneity and heterogeneity between groups. In the case of bottom-up analyses, the individuals in the sample are grouped by the degree of similarity between them, and in the case of top-down analyses, the sample is divided based on the variables with the greatest heterogeneity. In this study, a top-down cluster analysis was conducted using the Howard-Harris algorithm (Santesmases, 2009) on the sum of the two samples and an ANOVA table was produced, analysing the response of the different groups to the eight items. The analysis was performed based on the sum of the two samples due to the behaviour of the algorithm used. If each of the samples was analysed independently, there would be no guarantee that the generated groups had equivalent profiles for the two destinations. When performing the analysis on the sum of the two samples, the groups had the same profile in the two regions and only the proportion between groups varied. In addition, a cross tabulation of the groups and socio-demographic variables was carried out, highlighting the existing differences in relation to the region analysed.

To check if there were differences between groups or subsamples of data in the results tables, different statistical tools were used according to the type of data: A chi-squared test, to compare frequencies of variables with unordered categories; a t-test for the mean of two samples; and an F-test for a comparison of means of more than two samples. The three statistical tools take the absence of a statistically significant difference between samples as a null hypothesis. The P value indicates the probability of the null hypothesis and the null hypothesis being conventionally rejected when the P value is less than 0.05 , although it is better to use 0.01 or 0.001 as the critical value.

\section{Survey and Data Collection}

The main tool employed to carry out the analysis was a questionnaire with questions about the residents' attitudes and the socio-demographic profile of the interviewees. The questions on residents' attitudes consisted of a battery of items on various aspects related to tourism, and the interviewees indicated their degree of agreement or disagreement based on a five-point Likert scale (Maddox, 1985), with 1 being "strongly disagree", 3 "indifferent", and 5 "strongly agree". The items were adapted from the literature consulted (e.g., Gursoyand Rutherford, 2004; Gursoyet al., 2002). Within this battery of items, there were eight on aspects related to nightlife. These items are the same as those in the study of Serra 
\& Ramón (2017). There was also a battery of items referring to the degree of acceptance of different types of offers, including nightlife, measured with a five-point Likert scale, with 1 being "very unacceptable", 3 "indifferent", and 5 "very acceptable". The case studies carried out were on Ibiza (Spain) and Punta del Este (Uruguay).

For the fieldwork, convenience sampling was used since total randomness in the selection was impossible, due to the difficulty of accessing some residents. The questionnaires were distributed by interviewers at meeting points (shops, public squares, etc.) in different parts of the study areas, with the aim of reaching residents with difficult access for conducting surveys at home. A control of the demographic variables was carried out, with the aim of ensuring that the sample was representative of the population, controlling variables such as sex, age, place of residence, and employment situation. The incomplete questionnaires were eliminated from the recovered questionnaires, resulting in the definitive samples that were used in the analysis: 418 valid responses were obtained in Ibiza and 360 valid responses were obtained in Punta del Este, Maldonado. These samples present a maximum sampling error of $4.89 \%$ in the case of Ibiza and $5.25 \%$ in the case of Punta del Este, always considering a confidence level of $95.5 \%$. Being large samples and based on the Central Limit Theorem (Montgomery, \& Runger, 2003), the mean values have a distribution similar to the normal one.

Table 1. Socio-demographic profile of the samples.

\begin{tabular}{|c|c|c|c|c|c|c|}
\hline \multirow[t]{2}{*}{ 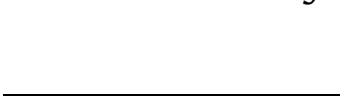 } & \multicolumn{2}{|c|}{ Ibiza } & \multicolumn{2}{|c|}{ Punta del Este } & \multicolumn{2}{|c|}{ Chi-Squared Test } \\
\hline & Frequency & $\%$ & Frequency & $\%$ & $\chi^{2}$ & P value \\
\hline Sex & & & & & 10.146 & 0.001 \\
\hline Male & 151 & $36.12 \%$ & 171 & $47 \cdot 50 \%$ & & \\
\hline Female & 266 & $63.64 \%$ & 189 & $52.50 \%$ & & \\
\hline Doesn't Answer & 1 & $0.24 \%$ & o & o & & \\
\hline Age & & & & & $25 \cdot 585$ & 0.000 \\
\hline Less than 25 & 55 & $13.16 \%$ & 73 & $20.28 \%$ & & \\
\hline From 25 to 34 & 102 & $24.40 \%$ & 79 & $21.94 \%$ & & \\
\hline from 35 to 44 & 98 & $23.44 \%$ & 63 & $17.50 \%$ & & \\
\hline from 45 to 54 & 88 & $21.05 \%$ & 62 & $17.22 \%$ & & \\
\hline 55 or more & 48 & $11.48 \%$ & 83 & $23.06 \%$ & & \\
\hline Doesn't Answer & 27 & $6.46 \%$ & o & o & & \\
\hline Level of studies & & & & & 49.593 & 0.000 \\
\hline Primary Studies & 92 & $22.01 \%$ & 18 & $5.00 \%$ & & \\
\hline Secondary Studies & 175 & $41.87 \%$ & 159 & $44.17 \%$ & & \\
\hline University Studies & 148 & $35.41 \%$ & 180 & $50.00 \%$ & & \\
\hline Doesn't Answer & 3 & $0.72 \%$ & 3 & $0.83 \%$ & & \\
\hline Birthplace & & & & & 39.661 & 0.000 \\
\hline In the region & 252 & $60.29 \%$ & 136 & $37.78 \%$ & & \\
\hline Outside the region & 165 & $39.47 \%$ & 224 & $62.22 \%$ & & \\
\hline Doesn't Answer & 1 & $0.24 \%$ & o & o & & \\
\hline Works in Tourism & & & & & 0.189 & 0.664 \\
\hline Yes & 256 & $61.24 \%$ & 214 & $59.44 \%$ & & \\
\hline No & 157 & $37 \cdot 56 \%$ & 140 & $38.89 \%$ & & \\
\hline Doesn't Answer & 5 & $1.20 \%$ & 6 & $1.67 \%$ & & \\
\hline
\end{tabular}




\section{Results}

The socio-demographic profile of the two samples obtained is shown in Table 1 and some of the most striking data are as follows: More women than men answered, but this bias is common in many studies; people with secondary or university studies predominate; and a very high proportion of the population was born outside the region and the majority works in tourism $(60 \%)$, which is common in the most important tourist destinations. The differences in the profile between the two samples may be due to different response propensities (for example, sex and birthplace in the case of Ibiza) or to differences in the region (for example, the level of studies in Punta del Este).

It should be pointed out that the nightlife supply in both destinations receives unenthusiastic ratings and the degree of acceptance is very moderate (Table 2). In both regions, clubber tourism is not considered to be quality tourism, with a supply aimed at tourists and that is inconvenient for the residents, although it is an important element for the image of the destination. In both regions, it is believed that the freedom of schedules in this sector should not be allowed and it is also believed that the residents are not taken into account when managing the sector. There is not a clear majority in favour of or against enhancing the sector.

Table 2. Average of the answers.

\begin{tabular}{|c|c|c|c|c|}
\hline & \multirow{2}{*}{$\begin{array}{l}\text { Ibiza } \\
\mathrm{n}=418\end{array}$} & \multirow{2}{*}{$\begin{array}{c}\text { Punta del Este } \\
n=360\end{array}$} & \multirow{2}{*}{$\begin{array}{l}\text { t } \\
\text { Test }\end{array}$} & \multirow{2}{*}{$\begin{array}{l}\mathbf{P} \\
\text { value }\end{array}$} \\
\hline & & & & \\
\hline I like the supply of nightlife leisure of the region. & 3.160 & 3.100 & 0.736 & 0.462 \\
\hline $\begin{array}{l}\text { Clubber tourism (tourists who come for the clubs) can } \\
\text { be considered quality tourism. }\end{array}$ & 2.062 & 2.686 & 8.173 & 0.000 \\
\hline $\begin{array}{l}\text { Nightclubs design leisure activities and special } \\
\text { promotions only aimed at tourists. }\end{array}$ & 3.763 & 3.014 & $9 \cdot 997$ & 0.000 \\
\hline $\begin{array}{l}\text { The major nightclubs of the region are a very important } \\
\text { component of the destination image. }\end{array}$ & 4.026 & $3 \cdot 331$ & 9.142 & 0.000 \\
\hline $\begin{array}{l}\text { Nightlife tourism generates drawbacks of noise, dirt and } \\
\text { traffic jam sat tolerable levels. }\end{array}$ & 3.856 & $3 \cdot 556$ & 4.111 & 0.000 \\
\hline $\begin{array}{l}\text { The sector of nightclubs, nightlife and electronic music } \\
\text { should been courage with the purpose of consolidating } \\
\text { the region as a world reference. }\end{array}$ & 2.806 & 3.203 & $4 \cdot 398$ & 0.000 \\
\hline $\begin{array}{l}\text { Flexible opening hours of nightclubs should be allowed } \\
\text { in order to ensure survival of a key sector in the } \\
\text { tourism image of the region. }\end{array}$ & 2.299 & 2.617 & 3.619 & 0.000 \\
\hline $\begin{array}{l}\text { Resident population views are taken into account when } \\
\text { managing the nightlife leisure sector. }\end{array}$ & 2.203 & 2.661 & 5.893 & 0.000 \\
\hline The nightlife supply is acceptable & 3.144 & 3.431 & 3.429 & 0.001 \\
\hline
\end{tabular}

After comparing the average values of the answers, it could be observed that there are no significant differences in the level of pleasure felt for the nightlife in the region (Table 2), even though the number, size, and prestige of the establishments in both regions are very different. This indicates that, in each region, residents are accustomed to the nightlife in that region, that it is valued in a moderately positive way, and that residents are unaware of external references with which to compare establishments in their own region. It is necessary to remember that nightlife is an activity with a very subjective valuation and is based on a person's experience, rather than on technical aspects. In the rest of the items proposed, 
Punta del Este displayed attitudes which are significantly more positive, or less negative, except in the valuation of the importance of nightclubs for the image of the region. In this case, Ibiza exhibited greater agreement with the statement. The sample from Ibiza is more opposed to considering nightclub tourism to be tourism of quality and allowing the freedom of schedules. A higher proportion of the residents also believe that nightlife generates discomfort and does not take residents into account in its management.

To meet the main objective of the study, a segmentation of both samples was carried out using the Howard-Harris algorithm. The statistical software used was DYANE 4.o (Santesmases, 2009) and the criterion for determining the number of groups was the maximum, which did not involve very small groups or groups with a confusing and poorly differentiated profile. In addition, taking into account the previous existing literature on residents' attitude segmentation (Ramón, \& Serra, 2015), the most likely initial options were three, four, or five groups. Finally, four groups was the option that met these criteria, two of which were supporters of nightlife supply (Enthusiasts and Moderates) and two of which were against nightlife supply (Critics and Negatives), as follows:

- Enthusiasts (21.72\%) show the highest degree of acceptance and support for the nightlife sector and its establishments. They like the nightlife supply of the region, although they consider that it is aimed at tourists. They are in favour of boosting this sector and are the only supporters of allowing the freedom of schedules. When asked if they consider that it attracts tourism of quality or if residents are taken into account, they do not show a clear stance in favour of or against these statements (Table 3 ). It is a group with more men, young people, individuals with university studies, and workers in the tourism sector (Table 4);

- Moderates (28.92\%) are fewer enthusiasts who also favour the nightlife supply; however, they show a low level of support for its future development and are not in favour of the freedom of schedules. This group does not like the existing supply in the region and is not clear about whether this supply attracts quality tourism. Nevertheless, they consider that this sector should be promoted as it is required for the image of the region, although they are not in favour of the freedom of schedules and considered that they are not taken into account (Table 3). The demographic profile of this group is quite similar to the average of the two samples (Table 4);

- Critics (27.51\%) are against this supply, but recognize the importance of nightclubs for tourism and the image of the destination. They do not like the nightlife supply of their region. They have the very clear opinion that it does not attract quality tourism and consider that it is strictly aimed at tourists. The nightlife in this region is a nuisance for this group, who believe that it must not be promoted. They are also the most against the freedom of schedules in this sector and consider that the opinions of the residents are not taken into account (Table 3). It is the group with the most women, people with primary studies, and individuals born in the region (Table 4);

- Negatives (21.85\%) show a negative stance towards the sector in terms of all the items mentioned above: They do not like the existing supply; it is not quality tourism; it is not important for the image of the destination; it generates discomfort; neither the freedom of schedules nor the sector should be promoted; and residents are not taken into account (Table 3). It has a significant proportion of women and it is the group with the most people born outside the region (Table 4). While the Critics show thoughtful opposition to the sector, acknowledging the positive and the negative, the Negatives simply respond with low scores to all questions. This is possibly because they do not have as deep of knowledge of nightlife in their region as other groups. 
Table 3. Results of the cluster analysis.

\begin{tabular}{|c|c|c|c|c|c|c|}
\hline & $\begin{array}{l}\text { Enthusiasts } \\
(21.72 \%)\end{array}$ & $\begin{array}{l}\text { Moderates } \\
(\mathbf{2 8 . 9 2} \%)\end{array}$ & $\begin{array}{l}\text { Critics } \\
(27.51 \%) \\
\end{array}$ & $\begin{array}{l}\text { Negatives } \\
(21.85 \%)\end{array}$ & F-Test & $P$ value \\
\hline $\begin{array}{l}\text { I like the supply of nightlife leisure } \\
\text { of the region. }\end{array}$ & 3.556 & 3.738 & 2.673 & 2.488 & 74.748 & 0.000 \\
\hline $\begin{array}{l}\text { Clubber tourism (tourists who come } \\
\text { for the clubs) can be considered } \\
\text { quality tourism. }\end{array}$ & 2.982 & 3.089 & 1.495 & 1.824 & 179.088 & 0.000 \\
\hline $\begin{array}{l}\text { Nightclubs design leisure activities } \\
\text { and special promotions only aimed } \\
\text { at tourists. }\end{array}$ & 3.467 & 3.169 & 4.140 & 2.782 & 66.227 & 0.000 \\
\hline $\begin{array}{l}\text { The major nightclubs of the region } \\
\text { are a very important component of } \\
\text { the destination image. }\end{array}$ & 4.237 & 4.000 & 4.229 & 2.124 & $349 \cdot 706$ & 0.000 \\
\hline $\begin{array}{l}\text { Nightlife tourism generates } \\
\text { drawbacks of noise, dirt and traffic } \\
\text { jams at tolerable levels. }\end{array}$ & 3.645 & 3.636 & 3.907 & 3.659 & $3 \cdot 374$ & 0.018 \\
\hline $\begin{array}{l}\text { The sector of nightclubs, nightlife } \\
\text { and electronic music should be } \\
\text { encouraged with the purpose of } \\
\text { consolidating the region as a world } \\
\text { reference. }\end{array}$ & 4.272 & 3.458 & 2.206 & 2.082 & 230.879 & 0.000 \\
\hline $\begin{array}{l}\text { Flexible opening hours of } \\
\text { nightclubs should be allowed in } \\
\text { order to ensure survival of a key } \\
\text { sector in the tourism image of the } \\
\text { region. }\end{array}$ & 4.331 & 2.240 & 1.687 & 1.800 & 543.788 & 0.000 \\
\hline $\begin{array}{l}\text { Resident population views are taken } \\
\text { into account when managing the } \\
\text { nightlife leisure sector. }\end{array}$ & 2.911 & 2.756 & 1.776 & 2.276 & 51.582 & 0.000 \\
\hline
\end{tabular}

Source: own elaboration.

In general, the two groups in favour of this sector (Enthusiasts and Moderates) include a greater proportion of men and workers in the tourism sector. On the contrary, the less enthusiastic groups (Critics and Negatives) involve a greater presence of women and people who do not work in the tourism sector. The two groups with the most homogeneous (Enthusiasts and Negatives) positions are those that contain more people born outside the region (Table 4 ).

The two groups in favour of this sector represent $58.61 \%$ of respondents in Punta del Este and $43.78 \%$ in Ibiza. The higher percentage in Punta del Este coincides with the highest degree of acceptance of this supply (Table 2). The Critics group makes up 42.82\% of respondents in Ibiza, but only 9.72\% in Punta del Este (Figure 1), being a consistent result with the increasing importance of this supply on the island of Ibiza (more importantly, more residents are affected by negative impacts) and the explanation of the differences between the two regions. The negative opinions about nightlife in Punta del Este are basically people from the group of Negatives, showing a "simpler" and more thoughtless view on this topic than the Critics. This is possibly because they are people who have spent little time residing in the region and who still do not know the sector sufficiently. In the case of Ibiza, the opposite opinions are mostly formed by the Critics, who are individuals with a more complex vision of the sector and, in a certain way, are more "rational", valuing aspects such as the sector importance for the tourist 
destination image. This shows that the negative responses are not "automatic" and are the result of a certain knowledge of the sector.

Table 4. Socio-demographic profile of the clusters.

\begin{tabular}{|c|c|c|c|c|c|c|}
\hline & $\begin{array}{l}\text { Enthusiasts } \\
(\mathbf{2 1 . 7 2 \% )}\end{array}$ & $\begin{array}{l}\text { Moderates } \\
(\mathbf{2 8 . 9 2 \% )}\end{array}$ & $\begin{array}{l}\text { Critics } \\
(27.51 \%) \\
\end{array}$ & $\begin{array}{l}\text { Negatives } \\
(21.85 \%)\end{array}$ & $\chi^{2}$ & $P$ value \\
\hline Sex & & & & & 20.092 & 0.000 \\
\hline Male & $51.48 \%$ & $46.22 \%$ & $30.37 \%$ & $38.82 \%$ & & \\
\hline Female & $48.52 \%$ & $53.78 \%$ & $69.16 \%$ & $61.18 \%$ & & \\
\hline Doesn't Answer & o & o & $0.47 \%$ & o & & \\
\hline Age & & & & & 18.773 & 0.094 \\
\hline Less than 25 & $24.26 \%$ & $13.33 \%$ & $14.02 \%$ & $15.88 \%$ & & \\
\hline From 25 to 34 & $27.22 \%$ & $23.11 \%$ & $22.43 \%$ & $20.59 \%$ & & \\
\hline from 35 to 44 & $17.16 \%$ & $20.00 \%$ & $23.36 \%$ & $21.76 \%$ & & \\
\hline from 45 to 54 & $13.02 \%$ & $21.78 \%$ & $19.63 \%$ & $21.76 \%$ & & \\
\hline 55 or more & $15.98 \%$ & $18.67 \%$ & $13.55 \%$ & $19.41 \%$ & & \\
\hline Doesn't Answer & $2.37 \%$ & $3.11 \%$ & $7.01 \%$ & $0.59 \%$ & & \\
\hline Level of studies & & & & & 10.680 & 0.099 \\
\hline Primary Studies & $10.65 \%$ & $11.56 \%$ & $19.16 \%$ & $14.71 \%$ & & \\
\hline Secondary Studies & $41.42 \%$ & $43.56 \%$ & $44.86 \%$ & $41.18 \%$ & & \\
\hline University Studies & $47 \cdot 34 \%$ & $43.56 \%$ & $35.05 \%$ & $44.12 \%$ & & \\
\hline Doesn't Answer & $0.59 \%$ & $1.33 \%$ & $0.93 \%$ & & & \\
\hline Birthplace & & & & & 13.643 & 0.003 \\
\hline In the region & $45.56 \%$ & $52.44 \%$ & $57.94 \%$ & $40.59 \%$ & & \\
\hline Outside the region & $54.44 \%$ & $47.56 \%$ & $41.59 \%$ & $59.41 \%$ & & \\
\hline Doesn't Answer & $\mathrm{o}$ & $\mathrm{o}$ & $0.47 \%$ & & & \\
\hline Works in Tourism & & & & & 8.600 & 0.035 \\
\hline Yes & $69.23 \%$ & $61.33 \%$ & $56.07 \%$ & $55.88 \%$ & & \\
\hline No & $29.59 \%$ & $37.33 \%$ & $42.99 \%$ & $41.76 \%$ & & \\
\hline Doesn't Answer & $1.18 \%$ & $1.33 \%$ & $0.93 \%$ & $2.35 \%$ & & \\
\hline Region & & & & & 115.001 & 0.000 \\
\hline Ibiza & $46.75 \%$ & $46.22 \%$ & $83.64 \%$ & $32.94 \%$ & & \\
\hline Punta del Este & $53.25 \%$ & $53.78 \%$ & $16.36 \%$ & $67.06 \%$ & & \\
\hline
\end{tabular}

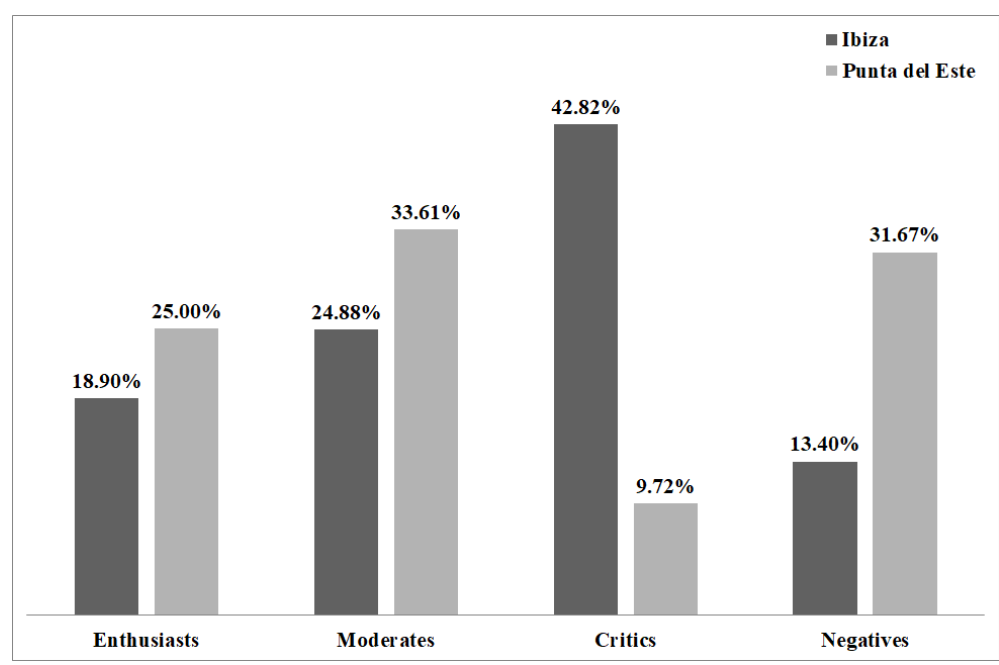

Figure 1. Distribution of the conserved groups, by region. 


\section{Conclusions}

There are no differences in the level of satisfaction that residents feel for the local nightlife supply, despite the significant differences in the development and prestige of nightlife in both regions. This indicates that residents do not have the capacity to value local nightlife compared to other regions. These simple data indicate that the valuation of nightclubs and bars is very subjective and subject to the experience of the patrons. Although the level of acceptance of nightlife is low in both tourist destinations, in Punta del Este, the residents have a slightly higher level of acceptance. Furthermore, for the remaining seven items analysed, significantly more favourable valuations were made in Punta del Este than in Ibiza.

In the segmentation carried out by means of descending cluster analysis, four groups were conserved, including two in favour of nightlife (Enthusiasts and Moderates) and two against nightlife (Critics and Negatives). In Punta del Este, the two favourable groups are more numerous than in Ibiza, but the main difference is in the composition of the block against nightlife (in Ibiza, the Critics predominate, and in Punta del Este, the Negatives predominate). This difference is possibly related to the size of the sector in the two regions analysed, being greater and better known in Ibiza than in Punta del Este, but it cannot be ruled out that there is a contamination of attitudes due to political debates unrelated to the true impacts of the sector, which is something that has happened in other cases when analysing the residents' attitudes towards tourism (Mantecón, \& Huete, 2011).

Ibiza is a world reference for tourism attracted by nightclubs, electronic music festivals, and nightlife in general. During the last few decades, the main nightclubs on the island have become famous worldwide and are examples for similar establishments around the world. Although there are groups in favour of this supply among the residents, the group of critics makes up more than $42 \%$ of the residents, which is a significant indication that it has been generating general unrest and opposition among a significant proportion of the residents. The nuisance generated by a very generous offer and the sense of impunity on behalf of the businessman in this sector have fostered a growth of criticism of a leisure activity that normally faces strong reluctance within the population. Punta del Este has a type of nightlife which is important for its image and completely different to the level of development in Ibiza. The nightclubs and bars are gathered in several areas (La Barra and the port), allowing the impact on residents and criticism to the industry to be minimized. In Punta del Este, nightlife is important, but as a tourist product, it is subject to the beaches, unlike Ibiza. Despite this, the evaluations made by residents are not much better than in the case of Ibiza, possibly due to the international image of a socially conflictive sector that nightlife has.

The groups in favour of nightlife are not a clear majority, as already sensed in Serra and Ramón (2017), contrary to what is usual in cluster analyses on tourism in general (Ramón, \& Serra, 2015). In the literature review of the cluster analysis on residents' attitudes (Ramón, \& Serra, 2015), it was found that the groups with positive attitudes represent a clear majority of the population; there is only one group of critics and it is a minority; there is a neutral group; and there are between one and three groups with positive positions, more or less nuanced. However, the first studies on residents' attitudes towards nightlife show that supporters and opposes are similarly abundant and when the sample is broken down in more detail, as in this case, more than one group opposed to the supply analysed appears for the first time. This is something of which we are not aware of being the case in previous literature on the segmentation of residents' attitudes towards tourism, although the results of Del Chiappa et al. (2019) on cruise tourism are similar. All this indicates that nightlife is a sector with greater social opposition and with attitude profiles that do not fit with the more conventional studies. 
Furthermore, there is a clear difference between regions (58.6\% favourable in Punta del Este and $43.8 \%$ favourable in Ibiza), with a majority of opposing positions being observed in the case of the region with the greatest development in the sector. From a theoretical point of view, the differences in the acceptance degree and in the group distribution between Ibiza and Punta del Este are consistent with the irritation index or Irridex of Doxey (1975), since, in the destination with the greatest nightlife development, there are more adverse positions, although new studies would be required to confirm its validity for nightlife.

In coastal tourist destinations, the nightlife complements daytime leisure (mainly beaches and water activities) and its absence would seriously damage the supply of the tourist destination. Therefore, the elimination of nightlife is not a viable option and it should be correctly managed in terms of the size, location, types, hours, etc. A balance must be struck between nightlife and residents to facilitate future success. This implies that the tourist destination managers must take consensual measures with the groups involved and take into account some basic ideas: Nightlife should be aimed at tourists and residents, to prevent the local population from feeling excluded; consulting businessmen in the sector makes it easier to get their support for the measures taken and consulting residents makes their attitudes more favourable, so a well-conducted negotiation will improve everyone's opinions, regardless of the outcome of the negotiation; all human activity has impacts on the economic, social, cultural, and natural environment; and managers must seek to maximize positive impacts and minimize negative ones. Some measures that should be analysed are the determination of schedules and exceptions. It is necessary to determine opening time slots for each type of establishment, reduce the overlap between types of supply, and avoid nightlife hours that cover many hours of the day. Until 2008, in some municipalities of Ibiza, there was a freedom of hours and a party situation occurred 24 hours a day, damaging beach businesses, the neighbours, and the management of these establishments. Another important measure is guaranteeing sound proofing of the nightclubs, limiting the outdoor performances, and adequately managing the cleanliness and safety of the public roads adjacent to the clubs. This would reduce the inconvenience facing the neighbours and avoid a bad image of nightclubs. Linked to the above and whenever possible, the nightlife supply should be located in remote areas of residential areas: Industrial estates with no activity at night and specialized areas located on the outskirts of towns, such as La Barra in Punta del Este; among other options. Pedagogy of the tourism sector must also be obtained so that people who do not work directly in the sector understand the importance of tourism for the region and are more understanding with businessmen, workers, and administrations. These are just some of the reflections that can be made about the management of a complex sector, as it depends on the subjective perception of the patrons and is controversial due to the negative impacts associated with it.

The main limitation is that the study is based on a convenience sample, thus rendering findings hardly generalizable to the entire population and segmentation improves the vision of reality, but still does not show all the details of the heterogeneous society. Another limitation is that the differences in the profile of the sample could have generated some of the differences in the results in both destinations. These differences in the sample profile may be due to the way in which the fieldwork had to be carried out. For this reason, it is necessary to carry out multiple studies with different techniques before firmly affirming certain conclusions. For example, future research should investigate other destinations with a significant presence of this supply, in order to check whether the presence of critics in Ibiza is an isolated case or a tendency due to the development of clubs, festivals, and bars. In general, there is a lot of work to be done in researching nightlife from the perspectives of management, economics, and marketing. 


\section{References}

Aagerup, U. (2020). Building nightclub brand personality via guest selection. International Journal of Hospitality Management, 85, e102336.

AETIB (2019). El turisme a les IllesBalears: Anuari 2018. Palma: Agènciad' Estratègia Turística de les Illes Balears (Govern de les Illes Balears).

Allen, B. et al. (2020). Delivering opioid overdose prevention in bars and nightclubs: A public awareness pilot in New York City. Journal of Public Health Management and Practice, 26(3), 232-235.

Allmark, P., \& Stratton, J. (2019). Into the groove: Experiencing difference in the Perth nightclub scene of the 1980s. Social Identities, 25(5), 704-723.

Almeida, F., Peláez, M.A., Balbuena, A., \& Cortés, R. (2016). Residents' perceptions of tourism development in Benalmádena (Spain). Tourism Management, 54, 259-274.

Andersson, J. (2011). Vauxhall's post-industrial pleasure gardens: 'Death Wish' and hedonism in 21stcentury London. Urban Studies, 48(1), 85-100.

Ap, J. (1992). Residents' perceptions on tourism impacts. Annals of Tourism Research, 19(4), 665-690.

Ap, J., \& Crompton, J.L. (1998). Developing and testing a tourism impact scale. Journal of Travel Research, 37(2), 120-130.

Aramayona, B., \& García, R. (2019). Decoding middle-class protest against low-cost nocturnal tourism in Madrid. Journal of Policy Research in Tourism, Leisure and Events, 11(3), 380-393.

Baldor, T. (2019). No girls allowed? Fluctuating boundaries between gay men and straight women in gay public space. Ethnography, 20(4), 419-442.

Berrozpe, A., Campo, S., \& Yagüe, M.J. (2017). Understanding the identity of Ibiza, Spain. Journal of Travel \& Tourism Marketing, 34(8), 1033-1046.

Besculides, A., Lee, M., \& McCormick, P. (2002). Resident's perceptions of the cultural benefits of tourism. Annals of Tourism Research, 29(2), 303-319.

Biagi, B., Ladu, M. G., Meleddu, M., \& Royuela, V. (2020). Tourism and the city: The impact on residents' quality of life. International Journal of Tourism Research, 22(2), 168-181.

Butler, R. W. (1980). The concept of the tourist area life-cycle of evolution: Implications for management of resources. Canadian Geographer, 24(1), 5-12.

Buttram, M.E., Kurtz, S.P., \& Paul, R.J. (2017). Sexual risk behaviours associated with unlicensed driving among young adults in Miami's electronic dance music nightclub scene. Sexual Health, 14(6), 584586.

Buttram, M.E., Pagano, M.E., \& Kurtz, S.P. (2018). Residential proximity to electronic dance music nightclubs and associations with substance use, sexual behaviors, and related problems. Journal of Drug Issues, 48(1), 4-16.

Calafat, A. et al. (2013a). Nightlife, verbal and physical violence among young European holidaymakers: What are the triggers? Public Health, 127(10), 908-915.

Calafat, A. et al. (2013b). Sexual harassment among young tourists visiting Mediterranean resorts. Archives of Sexual Behavior, 42(4), 603-613.

Calegaro, V.C. et al. (2019). The role of personality in posttraumatic stress disorder, trait resilience, and quality of life in people exposed to the kiss nightclub fire. PLoS ONE, 14(7), eo220472.

Capellà, H. (2018). The Ibiza's Nightlife as a Bend from Marginalization to Tourism Centrality. In Pelc, S., \& Koderman, M. (Eds.) (2018). Nature, Tourism and Ethnicity as Drivers of (De) Marginalization: Insights to Marginality from Perspective of Sustainability and Development. Cham: Springer, 109-118.

Carlini, C.M., \& Sanchez, Z.M. (2018). Typology of nightclubs in São Paulo, Brazil: Alcohol and illegal drug consumption, sexual behavior and violence in the venues. Substance use and Misuse, 53(11), 1801-1810.

Chen, J.S., \& Hsu, C.H.C. (2001). Developing and validating a riverboat gaming impact scale. Annals of Tourism Research, 28(2), 459-476. 
Choi, Y. H., Song, H., Wang, J., \& Hwang, J. (2019). Residents' perceptions of the impacts of a casinobased integrated resort development and their consequences: The case of the Incheon area in South Korea. Journal of Destination Marketing and Management, 14, e100390.

Del Chiappa, G., \& Abbate, T. (2016). Island cruise tourism development: A resident's perspective in the context of Italy. Current Issues in Tourism, 19(13), 1372-1385.

Del Chiappa, G., Atzeni, M., \& Ghasemi, V. (2018). Community-based collaborative tourism planning in islands: A cluster analysis in the context of costa smeralda. Journal of Destination Marketing and Management, 8, 41-48.

Del Chiappa, G., Atzeni, M., Pung, J. M., \& Risitano, M. (2019). Residents' views on cruise tourism in Naples profiles and insights from a Mediterranean home-port destination. European Journal of Tourism Research, 23, 71-85.

Dimitrijević, S. M., Mijić, M. M., \& ŠumaracPavlović, D. S. (2020). Indoor sound level spectra of public entertainment premises for rating airborne sound insulation. Journal of the Acoustical Society of America, 147(3), EL215-EL220.

Downing, J. et al. (2011). Factors associated with risky sexual behaviour: A comparison of British, Spanish and German holidaymakers to the Balearics. European Journal of Public Health, 21(3), 275-281.

Doxey, G.V. (1975). A causation theory of visitor-resident irritants: Methodology and research inferences. In The Impact of Tourism: Sixth Annual Conference Proceedings of the Travel Research Association (pp. 195-198). San Diego, CA: TTRA.

Eldridge, A. (2019). Strangers in the night: Nightlife studies and new urban tourism. Journal of Policy Research in Tourism, Leisure and Events, 11(3), 422-435.

Figueiredo, E., Kastenholz, E., \& Pinho, C. (2014). Living in a rural tourism destination - exploring the views of local communities. Revista Portuguesa de Estudos Regionais, 36(1), 3-12.

Garau, J.B., Díaz, R., \& Gutierrez, D. (2014). Residents' perceptions of tourism impacts on island destinations: A comparative analysis. International Journal of Tourism Research, 16(6), 578-585.

Garcia, L. (2018). Agonistic festivities: Urban nightlife scenes and the sociability of 'anti-social' fun. Annals of Leisure Research, 21(4), 462-479.

Gon, M., Osti, L., \& Pechlaner, H. (2016). Leisure boat tourism: Residents' attitudes towards nautical tourism development. Tourism Review, 71(3), 180-191.

Griffin, M., Callander, D., Duncan, D.T., \& Palamar, J.J. (2020). Differential risk for drug use by sexual minority status among electronic dance music party attendees in New York City. Substance use and Misuse, 55(2), 230-240.

Gursoy, D., \& Rutherford, D. (2004). Host attitudes toward tourism: An improved structural model. Annals of Tourism Research, 31(3), 495-516.

Gursoy, D., Jurowski, C., \& Uysal, M. (2002). Resident attitudes: A structural modelling approach. Annals of Tourism Research, 29(1), 79-105.

Hernandez, S.A., Cohen, J., \& Garcia, H.L. (1996). Residents' attitudes towards an instant resort enclave. Annals of tourism research, 23(4), 755-779.

Homan, S. (2019). 'Lockout' laws or 'rock out' laws? Governing Sydney's night-time economy and implications for the 'music city'. International Journal of Cultural Policy, 25(4), 500-514.

Houser, C. (2018). Art, nightlife and the complexities of participation: New York's area (1983-87). Journal of Curatorial Studies, 7(2), 152-182.

Ibestat (2020). Estadísticas. Palma: Institutd'Estadística de les IllesBalears. URL: http://ibestat.caib.es/ (Accessed on 10.04.2020).

Jurowski, C., \& Gursoy, D. (2004). Distance effects on residents' attitudes toward tourism. Annals of Tourism Research, 31(2), 296-312.

Kamenidou, I.C., Mamalis, S.A., Kokkinis, G., \& Geranis, C. (2013). Image components of nightlifeclubbing destinations. Tourismos, 8(3), 99-112. 
Kang, S.K., Lee, C., Yoon, Y., \& Long, P.T. (2008). Resident perception of the impact of limited-stakes community-based casino gaming in mature gaming communities. Tourism Management, 29(4), 681694.

Kelly, D., Hughes, K., \&Bellis, M.A. (2014). Work hard, party harder: Drug use and sexual behaviour in young British casual workers in Ibiza, Spain. International Journal of Environmental Research and Public Health, 11(10), 10051-10061.

Kubacki, K., Skinner, H., Parfitt, S., \& Moss, G. (2007). Comparing nightclub customers' preferences in existing and emerging markets. International Journal of Hospitality Management, 26(4), 957-973.

Labhart, F. et al. (2020). Capturing drinking and nightlife behaviours and their social and physical context with a smartphone application-investigation of users' experience and reactivity. Addiction Research and Theory, 28(1), 62-75.

Lankford, S.V., \& Howard, D.R. (1994). Developing a tourism impacts attitude scale. Annals of Tourism Research, 21(1), 121-139.

Lee, C.K., Kim, J., \& Kim, J.S. (2018). Impact of a gaming company's CSR on residents' perceived benefits, quality of life, and support. Tourism Management, 64, 281-290.

Li, J.J., Liu, X., \& Ali, F. (2018). Work-related attitudes and behaviors: Empirical evidence from a casino destination. Journal of Destination Marketing and Management, 9, 175-183.

Lundberg, E. (2015). The level of tourism development and resident attitudes: A comparative case study of coastal destinations. Scandinavian Journal of Hospitality and Tourism, 15(3), 266-294.

Maddox, R.N. (1985). Measuring satisfaction with tourism. Journal of Travel Research, 23(3), 2-5.

Mantecón, A., \& Huete, R. (2011). Sociological insights on residential tourism: Host society attitudes in a mature destination. European Journal of Tourism Research, 4(2), 109-122.

Martinotti, G. et al. (2017). Substance-related psychopathology and aggressiveness in a nightlife holiday resort: Results from a pilot study in a psychiatric inpatient unit in Ibiza. Human Psychopharmacology, 32(3), e2586.

Ministerio de Turismo (2020). Estadísticas. Montevideo: Ministerio de Turismo. URL: http://www.mintur.gub.uy/ (Accessed on 10.04.2020).

Montgomery, D.C., \& Runger, G.C. (2003). Applied Statistics and Probability for Engineers (3th ed.). Hoboken, NJ: John Wiley \& Sons, Inc.

Nejati, M., Mohamed, B., \& Omar, S.I. (2014). Locals' perceptions towards the impacts of tourism and the importance of local engagement: A comparative study of two islands in Malaysia. Tourism, 62(2), $135-146$.

Nofre, J. (2013). "Vintage nightlife": Gentrifying Lisbon downtown. Fennia, 191(2), 106-121.

Nofre, J. et al. (2019). The 'Pink Street' in Cais do Sodré: Urban change and liminal governance in a nightlife district of Lisbon. Urban Research and Practice, 12(4), 322-340.

Nofre, J., Giordano, E., Eldridge, A., Martins, J.C., \& Sequera, J. (2018). Tourism, nightlife and planning: Challenges and opportunities for community liveability in la Barceloneta. Tourism Geographies, 20(3), 377-396.

Nunkoo, R., \& Ramkissoon, H. (2009). Applying the means-end chain theory and the laddering technique to the study of host attitudes to tourism. Journal of Sustainable Tourism, 17(3), 337-355.

Nunkoo, R., Smith, S. L. J., \& Ramkissoon, H. (2013). Residents' attitudes to tourism: A longitudinal study of 140 articles from 1984 to 2010. Journal of Sustainable Tourism, 21(1), 5-25.

O'Leary, J., Huan, T., Briggs, D., \& Turner, T. (2012). Understanding British youth behaviors on holiday in Ibiza. International Journal of Culture, Tourism and Hospitality Research, 6(1), 81-90.

Özel, Ç.H., \& Kozak, N. (2017). An exploratory study of resident perceptions toward the tourism industry in Cappadocia: A social exchange theory approach. Asia Pacific Journal of Tourism Research, 22(3), 284-300. 
Palamar, J.J., \& Keyes, K.M. (2020). Trends in drug use among electronic dance music party attendees in New York City, 2016-2019. Drug and Alcohol Dependence, 209, e107889.

Palamar, J.J., Griffin-Tomas, M., Acosta, P., Ompad, D.C., \& Cleland, C.M. (2018). A comparison of selfreported sexual effects of alcohol, marijuana, and ecstasy in a sample of young adult nightlife attendees. Psychology and Sexuality, 9(1), 54-68.

Pavlić, I., Portolan, A., \& Puh, B. (2020). Segmenting local residents by perceptions of tourism impacts in an urban world heritage site: The case of Dubrovnik. Journal of Heritage Tourism, 15(4), 398-409.

Plyushteva, A. (2019). Commuting and the urban night: Nocturnal mobilities in tourism and hospitality work. Journal of Policy Research in Tourism, Leisure and Events, 11(3), 407-421.

Quigg, Z., Bigland, C., Hughes, K., Duch, M., \& Juan, M. (2020). Sexual violence and nightlife: A systematic literature review. Aggression and Violent Behavior, 51, e101363.

Ramón, E. (2001). Historia del turismo en Ibiza y Formentera. 1900-200o. Eivissa: Genial Ediciones Culturals.

Ramón, J., \& Serra, A. (2014). Historia del turismo en Ibiza: AplicacióndelCiclo de Vida del destinoTurísticoen un destinomaduro del Mediterráneo. PASOS: Revista de Turismo y Patrimonio Cultural, 12(4), 899-913.

Ramón, J., \& Serra, A. (2015). Segmentandoresidentessegún sus actitudes: Revisión de la literatura. PASOS: Revista de Turismo y Patrimonio Cultural, 13(4), 837-848.

Ramón, J., Azpelicueta, M.C., Abril, M., \& Sánchez, M.D. (2020). Management of tourism innovation, music and nightlife: Case study. In Ratten, V., Braga, V., Álvarez, J.,\&del Río, M.C. (Eds.) (2020). Tourism Innovation: Technology, Sustainability and Creativity. London: Routledge, 66-78.

Rasoolimanesh, S.M., Ringle, C.M., Jaafar, M., \& Ramayah, T. (2017). Urban vs. rural destinations: Residents' perceptions, community participation and support for tourism development. Tourism Management, 60, 147-158.

Rees, W. (2019). 'Got to be real': Evaluating the significance of realness in 1970s New York disco culture. European Journal of American Culture, 38(3), 239-253.

Ribeiro, M.A., Valle, P.O., \& Silva, J.A. (2013). Residents' attitudes towards tourism development in Cape Verde islands. Tourism Geographies, 15(4), 654-679.

Rivera, L.A. (2010). Status distinctions in interaction: Social selection and exclusion at an elite nightclub. Qualitative Sociology, 33(3), 229-255.

Sanchez, Z.M., Santos, M.G.R., Sanudo, A., Carlini, C.M., \& Martins, S.S. (2019). Sexual aggression in Brazilian nightclubs: Associations with Patron's characteristics, drug use, and environmental factors. Archives of Sexual Behavior, 48(2), 609-618.

Santesmases, M. (2009). DYANE Versión 4: Diseño y análisis de encuestas en investigación social y de mercados. Madrid: Ediciones Pirámide.

Serra, A., \& Ramón, J. (2017). Host community resignation to nightclub tourism. Current Issues in Tourism, 20(6), 566-579.

Sharpley, R. (2014). Host perceptions of tourism: A review of the research. Tourism Management, 42, 3749.

Sinclair-Maragh, G., Gursoy, D., \& Vieregge, M. (2015). Residents' perceptions toward tourism development: A factor-cluster approach. Journal of Destination Marketing and Management, 4(1), 3645 .

Skinner, H., Kubacki, K., Parfitt, S., \& Moss, G. (2008). Polish nightclubs and bars: Management insights into what customers really want. Journal for East European Management Studies, 13(2), 154-169.

Skinner, H., Moss, G., \& Parfitt, S. (2005). Nightclubs and bars: What do customers really want? International Journal of Contemporary Hospitality Management, 17(2), 114-124.

Smith, C.P. et al. (2020). Injury characteristics of the pulse nightclub shooting: Lessons for mass casualty incident preparation. Journal of Trauma and Acute Care Surgery, 88(3), 372-378. 
Smith, E.R., Shapiro, G., \&Sarani, B. (2018). Fatal wounding pattern and causes of potentially preventable death following the pulse night club shooting event. Prehospital Emergency Care, 22(6), 662-668.

Søgaard, T.F., \& Krause-Jensen, J. (2019). Bouncer service work: Emotional labour and flexible masculinity. Journal of Organizational Ethnography, 9(1), 30-43.

Sönmez, S., Apostolopoulos, Y., Theocharous, A., \& Massengale, K. (2013). Bar crawls, foam parties, and clubbing networks: Mapping the risk environment of a Mediterranean nightlife resort. Tourism Management Perspectives, 8, 49-59.

Stylidis, D., Terzidou, M., \& Terzidis, K. (2008). Islands and destination image: The case of Ios. Tourismos, 3(1), 180-199.

Sutton, R., \& Griffiths, M. D. (2008). The casino attitudes scale: The development of a new brief psychometric instrument. International Journal of Mental Health and Addiction, 6(2), 244-248.

Todorovic, M., \& Bakir, A. (2005). Inaudible noise: Belgrade's Academy Club: Legacy, old locals and new spaces. Leisure Studies, 24(4), 415-434.

Tomsen, S. (2018). Homicides with direct and indirect links to the night-time economy. Drug and Alcohol Review, 37(6), 794-801.

Turner, T. (2018). Disneyization: A framework for understanding illicit drug use in bounded play spaces. International Journal of Drug Policy, 58, 37-45.

Tutenges, S. (2012). Nightlife tourism: A mixed methods study of young tourists at an international nightlife resort. Tourist Studies, 12(2), 131-150.

Tutenges, S. (2013). Stirring up effervescence: An ethnographic study of youth at a nightlife resort. Leisure Studies, 32(3), 233-248.

Vareiro, L.M.C., Remoaldo, P.C., \& Ribeiro, J.A. (2013). Residents' perceptions of tourism impacts in Guimarães (Portugal): A cluster analysis. Current Issues in Tourism, 16(6), 535-551.

Xiaoping, Z., Zhu, H., \& Deng, S. (2014). Institutional ethical analysis of resident perceptions of tourism in two Chinese villages. Tourism Geographies, 16(5), 785-798.

Received: 31/05/2020

Accepted: 05/02/2021

Coordinating editor: Giacomo Del Chiappa 